\title{
Succession is threatening the large population of Lycopodiella inundata (L.) Holub. on anthropogenic site
}

\author{
Marcin Kiedrzyński', Monika Bogdanowicz², Anna Śliwińska-Wyrzychowska² \\ ${ }^{1}$ Department of Geobotany and Plant Ecology, Faculty of Biology and Environmental Protection, \\ University of Łódź, Banacha 12/16, 90-237 Łódź, Poland \\ ${ }^{2}$ Institute of Chemistry, Enviromental Protection and Biotechnology, Faculty of Mathematics and Natural Sciences, \\ Jan Długosz University in Częstochowa, \\ Ave. Armii Krajowej 13/15, 42-200 Częstochowa, Poland, \\ e-mail: a.wyrzychowska@gmail.com
}

\begin{abstract}
Lycopodiella inundata is an endangered, wetland species, able to occur in secondary, anthropogenic habitats. The article presents five-year changes in the occurrence of Lycopodiella inundata on the one of the largest stands in Central Poland. Chosen parameters of population were examined in different stages of vegetation succession. In open thickets the number of fertile stems was near three times higher and amounted above eight hundred fertile stems per square meter. In contrast, in patches with dense herb- and shrub-layer, the low number of fertile stems of $L$. inundata, have been observed. At anthropogenic sites, where $L$. inundata occurs, active protection should be made for the inhibition of succession and for the rejuvenation of habitat.
\end{abstract}

Key words: marsh clubmoss, Lycopodiella inundata, vegetation succession, pioneer species, anthropogenic habitats.

\section{Introduction}

The constant development of civilization involves both intentional and incidental changes in the natural environment (Crutzen \& Steffen 2003). In the case of wetlands, amelioration measures involved drainage and lead to the reduction of natural habitats (Amezaga et al. 2002; Haslam 2003; Kopeć \& Michalska-Hejduk 2012). At the same time human activities can contribute to the creation of surrogate, wetland habitats suitable for the occurrence of some endangered plants (Kołodziejek 1999). Apophytisation of rare species is observed especially in the case of plants with a good opportunities for effective, long-distance dispersion, e.g. orchids (Rewicz et al. 2015). Other examples can be found within the spore-bearing plants, including clubmosses and among them marsh clubmoss Lycopodiella inundata (L.) Holub.
The natural habitats for Lycopodiella inundata are raised and transitional peat bogs as well as wet heaths (Matuszkiewicz 2001; Wójciak 2003). However, it can be rarely met even there (Spałek 2004). Lycopodiella inundata is recognized as a diagnostic species for pioneer plant communities on humid exposed peat or sometimes on wet sand (Matuszkiewicz 2001). Such communities, belonging to the Rhynchosporion alliance are in the European Union protected as Natura 2000 habitat (code: 7150) (Interpretation Manual 2013). Lycopodiella inundata is also an important species in terms of the European biodiversity and listed in Annex V of the Habitat Directive (Council Directive 1992). In Poland L. inundata, as well as other clubmosses, is a law protected species (Rozporządzenie 2014). In the Red List of vascular plants of Poland it was declared as an endangered species - category V (Zarzycki $\&$ Szeląg 2006). The species was also included in the New 
Table 1. Floristic composition of different stages of succession with the participation of Lycopodiella inundata in anthropogenic site in Siedlów (Central Poland)

\begin{tabular}{|c|c|c|}
\hline Species & Stage A & Stage B \\
\hline \multicolumn{3}{|l|}{ Shrub layer } \\
\hline Pinus sylvestris & 2 & 3 \\
\hline Betula pendula & . & + \\
\hline \multicolumn{3}{|l|}{ Herb layer } \\
\hline Calluna vulgaris & 2 & 3 \\
\hline Lycopodiella inundata & 2 & 2 \\
\hline Pinus sylvestris & 1 & 2 \\
\hline Juncus articulatus & 1 & 1 \\
\hline Juncus conglomeratus & 1 & . \\
\hline Calamagrostis epigejos & + & + \\
\hline Carex sp. & + & + \\
\hline Juncus effusus & + & + \\
\hline Nardus stricta & + & + \\
\hline Potentilla erecta & + & + \\
\hline Vaccinium vitis-idaea & $\mathrm{r}$ & + \\
\hline Drosera rotundifolia & $\mathrm{r}$ & $\mathrm{r}$ \\
\hline Equisetum sp. & $\mathrm{r}$ & $\mathrm{r}$ \\
\hline Leontodon autumnalis & $\mathrm{r}$ & . \\
\hline Lysimachia vulgaris & $\mathrm{r}$ & . \\
\hline Lythrum salicaria & $\mathrm{r}$ & . \\
\hline Agrostis tennuis & . & + \\
\hline Betula pendula & . & + \\
\hline Carex panicea & . & + \\
\hline Lycopodium clavatum & . & + \\
\hline Salix cinerea & . & + \\
\hline Sieglingia decumbens & . & + \\
\hline Vaccinium myrtillus & . & + \\
\hline Antoxantum odoratum & . & $\mathrm{r}$ \\
\hline Carex hirta & . & $\mathrm{r}$ \\
\hline Hieracium sp. & . & $\mathrm{r}$ \\
\hline Padus serotina & . & $\mathrm{r}$ \\
\hline Rubus sp. & . & $\mathrm{r}$ \\
\hline Salix purpurea & . & $\mathrm{r}$ \\
\hline Solidago virgaurea & . & $\mathrm{r}$ \\
\hline \multicolumn{3}{|l|}{ Moss and lichen layer } \\
\hline Aulacomnium palustre & 3 & 1 \\
\hline Polytrichum commune & 1 & + \\
\hline Cladonia arbuscula & + & + \\
\hline Cladonia rangiferina & + & + \\
\hline Cladonia uncialis & + & + \\
\hline Cladonia coccifera & . & $\mathrm{r}$ \\
\hline
\end{tabular}

Red list of Polish wetland flora and listed as vulnerable VU category (Kopeć \& Michalska-Hejduk 2012).

Recently in Poland, new localities of $L$. inundata are often discovered in the anthropogenic habitats (Spałek 2003; Urbisz \& Urbisz 1998). They include wet sites formed in the immediate vicinity of the dam reservoirs (Hereźniak \& Samosiej 1990) or the edges of ponds and surrounding wetlands, on which patches of peat bogs could be formed (Spałek 2003). The second group of anthropogenic habitats suitable for marsh clubmoss are excavations of sand or clay (Cieszko \& Kucharczyk 1997, 1999; Czarnecka 2000). All of these sites include early stages of succession, where the ecological competition is relatively low. In such places, optimal conditions for the development of L. inundata occur: strong sunlight, humidity of substrate (wet habitat) and low fertility, acidic soil (oligo- or mesotrophic) (Zarzycki et al. 2002).

Lycopodiella inundata may therefore be an example of an endangered species in Central Europe able to occur in an anthropogenic landscape in secondary habitats. The question is: how long populations of $L$. inundata live in the secondary habitats and what factors could cause its disappearance?

The aim of the paper is to present the five-year changes of $L$. inundata occurrence on the anthropogenic habitat in Central Poland. Moreover, the impact of vegetation structure, in different stages of succession, on the density of L. inundata, have been studied.

\section{Materials and methods}

\subsection{Study site}

In the 2008, during the botanical investigation in the Natura 2000 site: "Valley of the Czarna River", new locality of Lycopodiella inundata have been discovered near the Siedlów village. The locality is situated in the Opoczno Hills within the Polish Uplands. Two subpopulations of L. inundata (georeferences: 51.19217, 20.12577 and $51.19392,20.10304), 1,600 \mathrm{~m}$ away from each other, have been found (Kiedrzyński \& Łuczak 2008, unpublished data). The first subpopulation, which occupies the area $25 \mathrm{~m}^{2}$, grows in wet grassland with Nardus stricta and Hydrocotyle vulgaris. The second subpopulation - object of presented study - is larger $\left(1,400 \mathrm{~m}^{2}\right)$ and grows in the anthropogenic habitat, which was created during the construction of fish ponds (Fig. 1A, B).

\subsubsection{Stages of succession in the study site}

The barren surface is going to fast overgrown by vegetation (Fig. 1 A, B). In 2008, Lycopodiella inundata grew here on wet, sandy ground, with occurrence of juvenile individuals 
of Pinus sylvestris and Calluna vulgaris. The changes in the structure of vegetation, between 2008 and 2013, were caused mostly by growth of pine trees and expansion of heather. However, the observed changes were irregular in different parts of the study site. In 2013 Lycopodiella inundata occurred in two different stages of succession (stage A and stage B, Table 1). Floristic composition typical for each stage were described by using the phytosociological method (Braun-Blanquet 1964) (Table 1).

The stage $\mathrm{A}$ is characterized by very low (15\%) density of trees and its maximal height $2.7 \mathrm{~m}, 30 \%$ cover of herb-layer and $80 \%$ cover of moss-layer. The stage $\mathrm{B}$ is characterized by higher density of trees $(40 \%)$ and its height up to $4.0 \mathrm{~m}, 60 \%$ cover of herb-layer and low (10\%) cover of moss-layer.

In the paper, nomenclature of vascular plants was used according to Mirek et al. (2002), moss nomenclature according to Ochyra et al. (2003) and lichens nomenclature according to Fałtynowicz (2003).

\subsection{Investigation of Lycopodiella inundata}

The area of occurrence of L. inundata in 2008 and 2013 was measured by using the polygon method with GPS receiver (Garmin CSX60). Visualizations of the results and measuring of the area occupied by L. innundata were performed in ArcMap 9.2 software (ESRI Inc. 1999-2008, Redlands, CA, USA).

The density of fertile, cone-bearing stems (stems with strobili) of L. inundata was investigated in 2013 in two succession stages (A and B) in plots of area $0.25 \mathrm{~m}^{2}$. At any succession stage 12 plots were performed.

In order to perform statistical analyzes the density of fertile stems per $1 \mathrm{~m}^{2}$ was calculated. Conservative Shapiro-Wilk test assessing the compliance the data distribution with normal distribution was used. Nonparametric Wald-Wolfowitz test for the assessment of differences in the density of L. inundata fertile stems in stages A and B was used (Stanisz 2006). Statistical analyses were performed using the Statistica 10 package (StatSoft 2011).

\section{Results}

\subsection{Changes in Lycopodiella inundata occurrence between 2008 and 2013}

In 2008 L. inundata occurred in the south part of the study site, in one, large patch (Fig. 1B). In that time, L. innundata occupied area of $1,417 \mathrm{~m}^{2}$. After five years, the range of L. inundata moved north and the area of the main patch decreased to $1,071 \mathrm{~m}^{2}$ (Fig. 1B). Moreover, in 2013 L. inundata was found in the second, isolated patch (Fig. 1B).
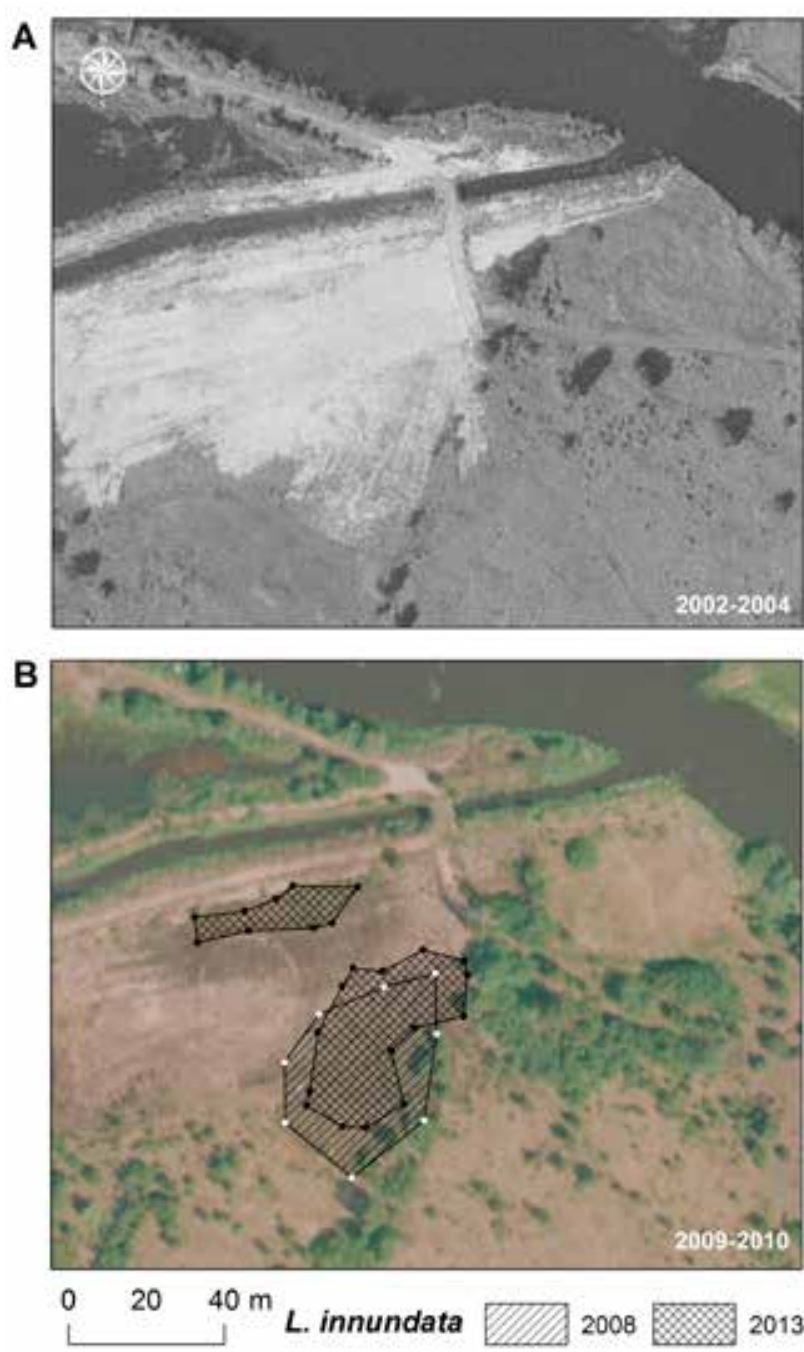

Figure 1. Locality of Lycopodiella inundata on the anthropogenic site in Siedlów under the Czarna River in Central Poland. A - sandy and wet habitat after the water channel creation. B - changes in area of L. inundata patches between 2008 and 2013. The orthophotmaps according to www.geoportal.pl

Its area was $306 \mathrm{~m}^{2}$ and the total area of L. inundata in 2013 stated $1,377 \mathrm{~m}^{2}$.

\subsection{Density of Lycopodiella inundata fertile stems in different stages of succession}

In open thickets (stage $\mathrm{A}$ ) the average number of fertile stems per $1 \mathrm{~m}^{2}$ exceeded 880 . In dense shrubs (stage B) the average number of fertile stems (275) was three times lower (Table 2, Figs. 2, 3). Shapiro-Wilk test showed that the data distributions in the both cases were significantly different from the normal distribution $(p=0.00657)$. The average density of L. inundata fertile stems in both stages 
Table 2. Density of Lycopodiella inundata fertile stems per square meter in different stages of succession in anthropogenic site in Siedlów (Central Poland)

\begin{tabular}{lccccccc}
\hline \multicolumn{1}{c}{ Succession stage } & Mean & Median & $\begin{array}{c}\text { Standard } \\
\text { Deviation }\end{array}$ & Minimum & Maximum & Kurtosis & No of plots \\
\hline A - open pine shrubs & 880.8 & 914 & 330.8 & 348 & 1456 & -0.66 & 12 \\
B - dense pine shrubs & 275.2 & 258 & 87.6 & 148 & 436 & 0.24 & 12 \\
\hline
\end{tabular}
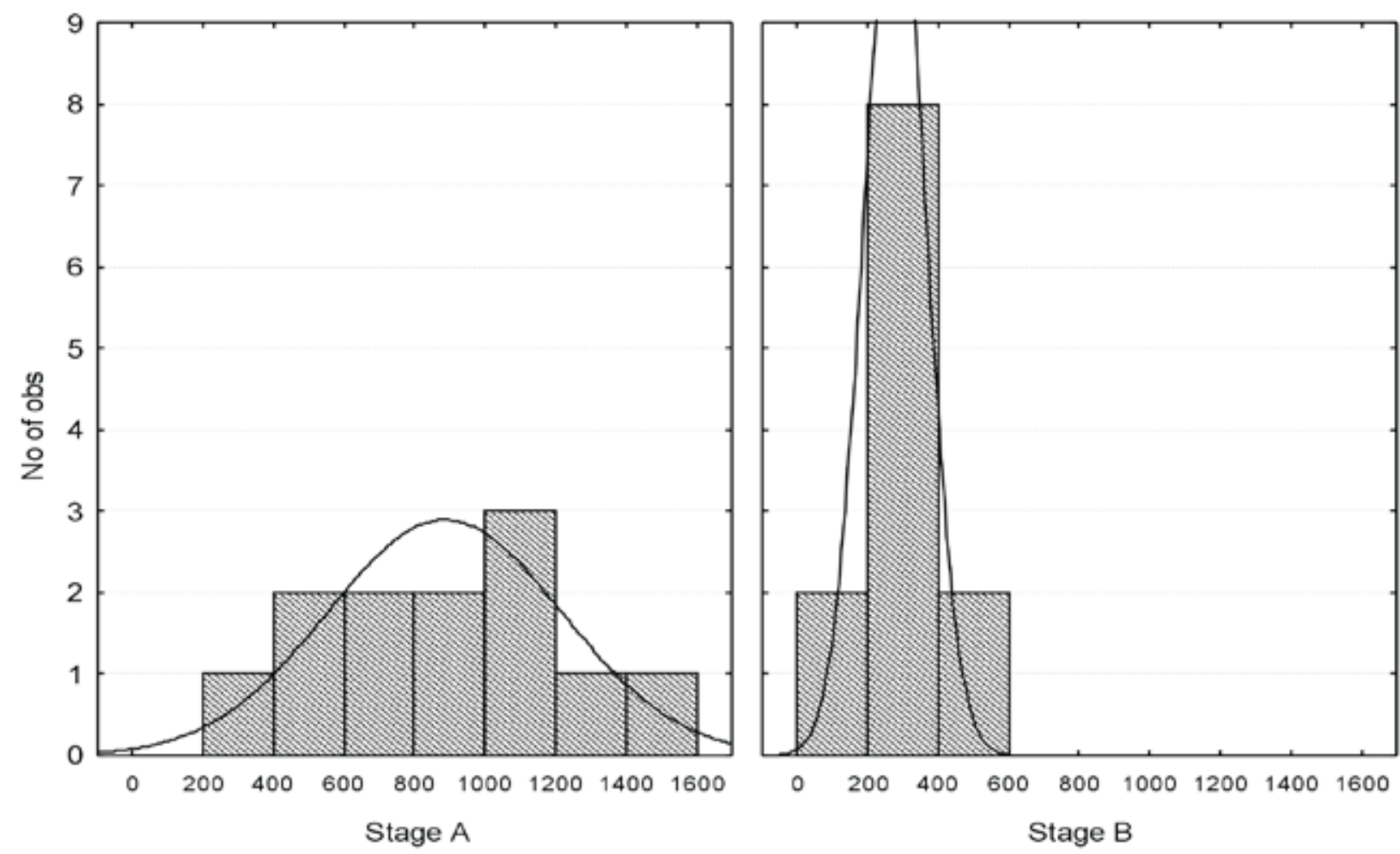

Number of fertile conebearing stems of $L$. inundata per $1 \mathrm{~m}^{2}$

Figure 2. Density of fertile stems of Lycopodiella inundata in different stages of succession in anthropogenic site in Central Poland (A - early stage with low cover of Calluna vulgaris, B - stage with high cover of Calluna vulgaris)

were different significantly from each other $(p=0.00039)$. Both sets of data are different in terms of the overall shape of the distribution. In stage A, kurtosis was -0.66 - the distribution is flatter than the normal distribution (Fig. 2). The data from stage $\mathrm{B}$ were much more concentrated around the mean value (kurtosis =0.24) (Fig. 2). In the stage A the number of $L$. inundata per $1 \mathrm{~m}^{2}$ was much more variable than in the stage $\mathrm{B}$, where the standard deviation was almost four times lower (Table 2).

\section{Discussion}

In many regions in Poland the disappearance of Lycopodiella inundata in natural habitats has been described. However, the recent occurrence of species in anthropogenic habitats is also well documented. For example, in the Silesian Upland (Southern Poland) in the mid $19^{\text {th }}$ and early $20^{\text {th }}$ centuries, L. inundata was recorded on 10 stands (Urbisz $\&$ Urbisz 1998 and cited literature). At the end of the $20^{\text {th }}$ century its presence on these localities was not confirmed, but six new localities were found (Urbisz \& Urbisz 1998). In the Rybnik Plateau and the Racibórz Basin the most of localities from late $19^{\text {th }}$ and early $20^{\text {th }}$ centuries (Urbisz 1996; Kowalczyk 2005 and the cited literature) were not 

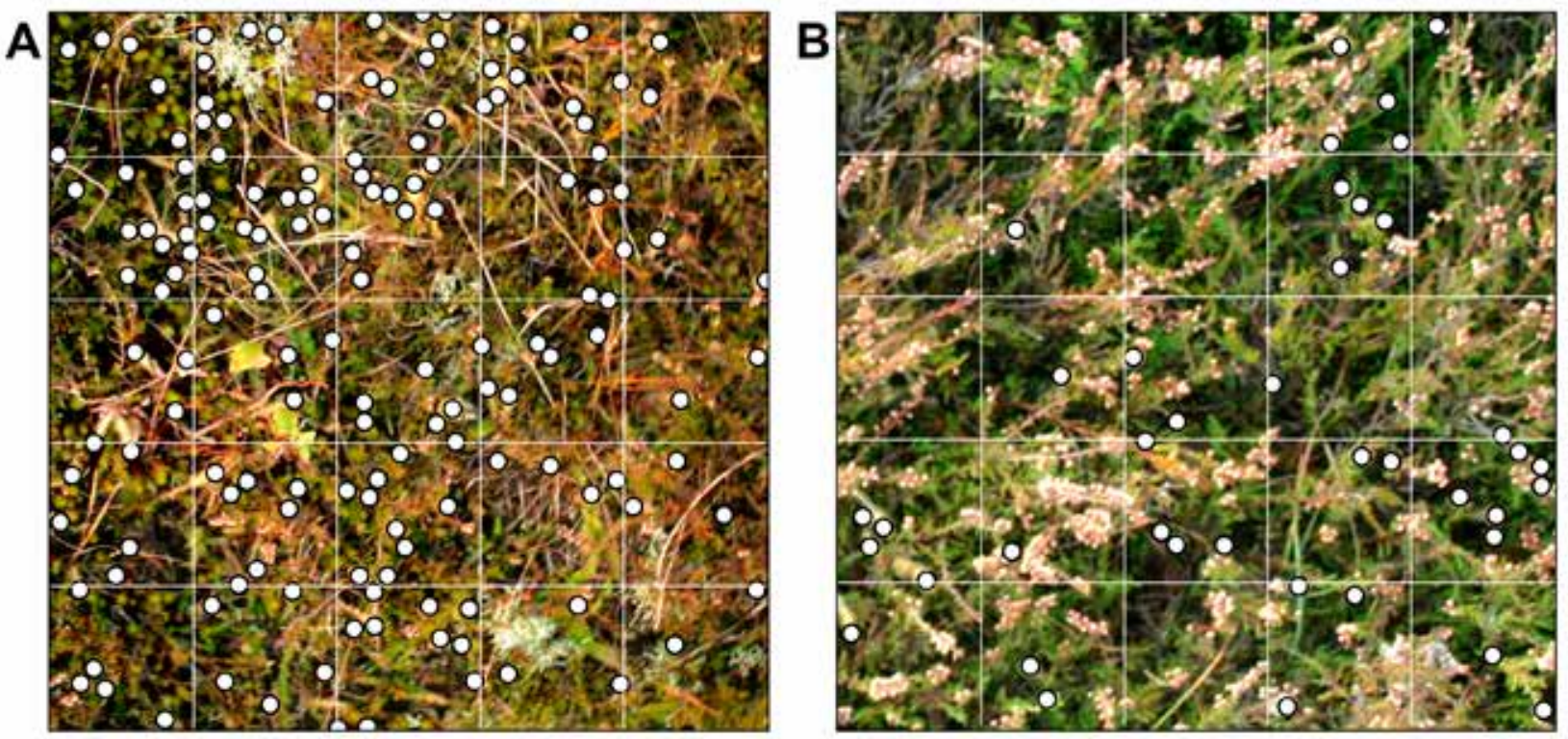

$10 \mathrm{~cm}$

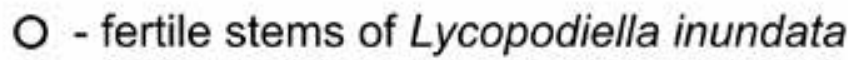

Figure 3. Differentiation of fertile stems density of Lycopodiella inundata on $0.25 \mathrm{~m}^{2}$ in different stages of succession in anthropogenic site in Siedlów (Central Poland). A - early stage with low cover of Calluna vulgaris and open pine shrubs, B - stage with high cover of Calluna vulgaris and dense pine shrubs

confirmed (Urbisz 1996). However, currently new ones localized in anthropogenic habitats have been found.

The size of marsh clubmoss populations in secondary habitats is very diverse: from the tens, by hundreds up to several thousand specimens. Most of the literature from Central Poland alludes to small populations, consisting of several or over a dozen of specimens (Kucharski \& Kurzac 1996; Jakubowska-Gabara et al. 2011). Taking into consideration the area occupied by L. inundata and density of fertile stems on the studied stand, we conclude, that the population in Siedlów is one of the largest currently known in Central Poland.

Anthropogenic habitats are characterized by an occurrence of initial stages of succession, with poorly developed herb- and shrub- layers. Our results showed that the distribution of L. inundata inside the anthropogenic habitats could change dynamically as a result of the formation of new patches or - as a result of disappearance of species during the progressive vegetation succession. In contrast to Lycopodium and Diphasiastrum species, development cycle of Lycopodiella inundata is quite short and does not take several or dozen years. Prothallium L. inundata can proceed to sexual reproduction after a year from sporulation (Artensteckbrief ..., 2009). Hence, the new available habitat can be quickly occupied by $L$. inundata stolons, especially in barren areas. Our results confirmed these statements. In the studied site a new patch $\left(300 \mathrm{~m}^{2}\right)$ of $L$. inundata has developed during 5 years.
The density of fertile stems depends also on the stage of succession and on the occurrence of competing species. The density of $L$. inundata fertile stems was significantly lower in patches with high density of Calluna vulgaris. The disappearance of L. inundata is connected also with the restriction of light availability, caused by development of pine-trees and heather.

Moreover, not only development of trees and herbs intensively occupying the space, could cause the disappearing of Lycopodiella inundata stems (or in general - sporophytes). Cieszko \& Kucharczyk (1997) found a negative relationship between occurrence of moss Polytrychum commune and L. inundata. The competition of these two species was important in the pioneer stage of succession. In our case, the development of herb- and shrub-layers has reduced the cover of both: bryophytes and L. inundata. Marsh clubmoss developed very well in stage A, where bryophytes also covered a large area ( $80 \%$ of the surface). However moss-layer was there dominated not by Polytrichum commune but by Aulaucomium palustre. In stage B, with dense heather and pine-trees, much smaller share of moss-layer (10\%) and lower density of L. inundata, have been noted.

Other authors suggest that changes in the number of $L$. inundata fertile stems, in anthropogenic habitats, may also depend on a groundwater level. For example, in a population growing at the bottom of the sand pit in the Middle Vistula Valley within one year the number of cone-bearing 
stems increased almost six-fold (from 56 cones in 1994 to 345 ones in 1995) (Czarnecka 2000). However, in 1997 there was observed a slight decrease in their number (314), as a result of prolonged flooding. Two years later, in the same population, the number of cone-bearing stems exceeded the number of 2,500 (Czarnecka 2000). Changes in population size may be caused also by too low groundwater level. Drainage occurs often as a result of the exploitation of deposits and increasing general industrialization and leads to the transformation of open, bog communities to scrub (Błońska 2010).

In anthropogenic sites, active protection of L. inunda$t a$ - heliophilous species, should be made by cuttings of shrubs and trees (Czylok \& Rahmonow 1996). In the study site removing of pine Pinus sylvestris from the shrub-layer and reducing of heather Calluna vulgaris in the undergrowth, should be made. Mentioned treatments should be made during the winter, what could minimize the risk of damage to L. inundata stems. Moreover, it is also advisable to create new barren areas, which could be occupied by L. inundata in the future. The "rejuvenation of habitat" should be made outside the actual range of L. inundata, by taking off the top layer of the substrate. Rejuvenation of habitat by artificial exposing of peat surface (or mineral-organic substrate) as a result of the removal of a layer of peat, herbs and shrubs, is also recommended for conservation of Natura 2000 habitat (7150) in the official conservation guide (Koczur 2012).

In the study site, the low number of fertile stems of L. inundata which occurs in advanced stage of succession, is a clear signal that in the near future the population could completely disappear. Described activities seem to be necessary to maintain the stand in Siedlów - one of the largest in Central Poland.

\section{Acknowledgments}

We would like to thank PhD Agnieszka Bąbelewska for help in determining the lichens.

\section{References}

Amezaga J. M., Santamaría L. \& Green A. J., 2002, Biotic wetland connectivity supporting a new approach for wetland Policy, Acta Oecologica 23: 213-222.

Artensteckbrief Sumpf-Bärlapp (Lycopodiella inundata), 2009, HESSEN-FORST, Fachbereich Forsteinrichtung und Naturschutz (FENA) Servicestelle für Forsteinrichtung und Naturschutz.

Błońska A., 2010, Siedliska antropogeniczne na Wyżynie Śląskiej jako miejsca występowania rzadkich i zagrożonych gatunków torfowiskowych klasy Scheuchze-
rio-Caricetea nigrae (Nordh. 1937) R. Tx 1937 [The anthropogenic sites on Silesian Upland as the habitats of rare and endangered marsh species of the Scheuchzerio-Caricetea nigrae class (Nordh. 1937) R. Tx 1937], Woda - Środowisko - Obszary - Wiejskie 10(29): 7-19.

Braun-Blanquet J. 1964. Plant sociology, Broad Vegetation Science. 3 Aufl. Springer, Wienn.

Cieszko J. \& Kucharczyk M., 1997, Nieczynne piaskownie jako wtórne siedliska występowania widłaczka torfowego Lycopodiella inundata (L.) Holub. [Closed sandpits as secondary biotopes of marsh club moss Lycopodiella inundata (L.) Holub. occurrence], [in]: S. Wika (ed.), Roślinność obszarów piaszczystych [Vegetation of sandy areas], Uniwersytet Śląski, Wydział Biologii i Ochrony Środowiska, Wydział Nauk o Ziemi, Katowice-Dabrowa Górnicza: 50-60.

Cieszko J. \& Kucharczyk M., 1999, Populacje widłaczka torfowego Lycopodiella inundata (L.) Holub. na siedliskach antropogenicznych [Populations of marsh club moss Lycopodiella inundata (L.) on anthropogenic habitats], Chrońmy Przyrodę Ojczystą: 55(2): 79-90.

Council Directive 92/43/EEC of 21 may1992 on the conservation of natural habitats and of wild fauna and flora, Annex V - Animal and plant species of Community interest whose taking in the wild and exploitation may be subject to management measures Directive 2006/105/EC [Official Journal L 363 of 20.12.2006].

Crutzen P.J. \& Steffen W., 2003, How long have we been in the anthropocene era? Climatic Change 61: 251-257.

Czarnecka J., 2000. Obszary silnie przekształcone szansą dla widłaczka torfowego Lycopodiella inundata [Hevily transformed areas - chance for marsh club moss Lycopodiella inundata], Przegląd Przyrodniczy 11(2-3): 65-72.

Czylok A. \& Rahmonow O., 1996, Unikatowe układy fitocenotyczne w wyrobiskach wschodniej części województwa katowickiego [Unique phytocoenosis systems situated in excavations of the eastern part of Katowice voivodship], Kształtowanie środowiska geograficznego i ochrona przyrody na obszarach uprzemysłowionych i zurbanizowanych 23: 27-31.

ESRI Inc., 1999-2008, ArcGIS Desktop TM 9.2, New York Street, Redlands, USA.

Fałtynowicz W., 2003, The Lichens, lichenicolous and allied fungi of Poland: An annotated checklist, W. Szafer Institute of Botany, Polish Academy of Science, Kraków.

Haslam S.M., 2003, Understanding Wetlands: Fen, Bog, and Marsh, London, UK, Taylor \& Francis.

Hereźniak J. \& Samosiej L., 1990, O potrzebie ochrony rezerwatowej Jeziora Blachownia koło Częstochowy [The necessity for reserve protection on Blachownia Lake near Częstochowa], Chrońmy Przyrodę Ojczystą 46(1): 35-46. 
Interpretation Manual of European Union Habitats. EUR 28, 2013, European Commission DG Environment, Nature ENV B.3, April 2013.

Jakubowska-Gabara J., Kucharski L., Zielińska K., Kołodziejek J., Witosławski P. \& Popkiewicz P., 2011, Atlas rozmieszczenia roślin naczyniowych w Polsce Środkowej. Gatunki chronione, rzadkie, ginące i narażone [Atlas of Vascular Plants Distribution in Central Poland. Legally protected, rare, endangered and vulnerable species], Uniwersytet Łódzki, Łódź.

Koczur A., 2012, Obniżenia na podłożu torfowym z roślinnością ze związku Rhynchosporion. [Depressions on peat substrates with the vegetation from the Rhynchosporion alliance], [in:] W. Mróz (ed.) Monitoring siedlisk przyrodniczych. Przewodnik metodyczny, Część III [Monitoring of Natural Habitats. Methodological Guide, Part 3], GIOŚ, Warszawa.

Kołodziejek J., 1999, Rzadkie i interesujące gatunki roślin naczyniowych na górniczo zniekształconych obszarach środkowej części Częstochowskiego Okręgu Rudonośnego [Rare and interesting vascular plant species in the mine-transformed areas of central part of Częstochowa Ore District], Fragm. Flor. Geobot. Polonica 6: 39-43.

Kowalczyk B., 2005, Chronione gatunki roślin naczyniowych północnej części Kotliny Raciborskiej i okolic [Protected species of vascular plants in the north part of the the Kotlina Raciborska and environs], Fragm. Flor. Geobot. Pol. 12(1): 97-111.

Kopeć D. \& Michalska-Hejduk D., 2012, How threatened is the Polish wetland flora? Oceanological and Hydrobiological Studies 41(3): 79-89.

Kucharski L. \& Kurzac M., 1996, Rozmieszczenie geograficzne Huperzia selago, Diphasium complanatum i Lepidotis inundata (Lycopodiaceae) w Środkowej Polsce. [Distribution of Huperzia selago, Diphasium complanatum and Lepidotis inundata (Lycopodiaceae) in Central Poland], Fragm. Flor. Geobot. Pol. 3: 131139.

Matuszkiewicz W., 2001, Przewodnik do oznaczania zbiorowisk roślinnych Polski [A guide for identification of the plant communities of Poland], Vademecum Geobotanicum 3, Wydawnictwo Naukowe PWN, Warszawa.

Mirek Z., Piękoś-Mirkowa H., Zając A. \& Zając M., 2002, Flowering plants and pteridophytes of Poland. A checklist, Władysław Szafer Insitute of Botany, Polish Academy of Sciences, Kraków.

Ochyra R., Żarnowiec J. \& Bednarek-Ochyra H., 2003, Census Catalogue of Polish Mosses: Biodiversity of Poland 3, Polish Academy of Sciences, Władysław Szafer Institute of Botany, Kraków.

RewiczA., Zielińska K.M., Kiedrzyński M. \& Kucharski L., 2015, Orchidaceae in the landscape of central Poland: diversity, extinction and conservation perspectives. Archives of Biological Sciences, 67(1): 119-130.

Rozporządzenie Ministra Środowiska z dnia 16 października 2014 roku w sprawie ochrony gatunkowej roślin, Dz. U. Nr 2014 poz. 1409 [Regulation of the Minister of the Environment of 16 October 2014 on the species of plants being under protection, Journal of Laws no. 210, item 1409], 2014.

Spałek K., 2003, Materiały do rozmieszczenia rzadkich i interesujących gatunków paprotników (Pteridophyta) na Równinie Opolskiej [Materials to the distribution of rare and interesting species of the Pteridophyta in the Opole Plain (SW Poland)], Fragm. Florist. Geobot. Pol. 10: 209-220.

Spałek K., 2004, Zbiorowiska z klasy Scheuchzerio-Caricetea nigrae na Równinie Opolskiej [Communities of the Scheuchzerio-Caricetea nigrae class in the Opole Plain], Fragm. Florist. Geobot. Pol. 11(2): 319-335.

Stanisz A., 2006, Przystępny kurs statystyki z zastosowanie STATISTICA PL na przykładach z medycyny, Tom 1 Statystyki podstawowe [The approachable course of statistics based on the STATISTICA PL software with medical Samales, Volume 1 Basic Statistics], StatSoft, Kraków.

StatSoft Inc [Internet], STATISTICA (data analysis software system) version 10, 2011, Available from: http:// www.statsoft.com.

Urbisz A. \& Urbisz A., 1998, Rośliny chronione południowo-zachodniej części Wyżyny Śląskiej [Protected plants on south-western part of Silesian Upland], Acta Biologica Silesiana 33(50): 113-142.

Urbisz A., 1996, Flora naczyniowa Płaskowyżu Rybnickiego na tle antropogenicznych przemian tego obszaru [Vascular flora of Rybnik Plateau against a background of anthropogenic transformations of this area], Scripta Rudensia 6, Park Krajobrazowy „Cysterskie Kompozycje Krajobrazowe Rud Wielkich”, Rudy Wielkie.

Wójciak H., 2003, Flora Polski. Porosty, mszaki, paprotniki [Lichens, bryophytes, pteridophytes], Oficyna Wydawnicza MULICO, Warszawa.

Zarzycki K. \& Szeląg Z., 2006, Czerwona lista roślin naczyniowych w Polsce [Red list of the vascular plants in Poland], [in:] Z. Mirek, K. Zarzycki, W. Wojewoda, Z. Szeląg (eds), Czerwona lista roślin i grzybów Polski [Red list of plants and fungi in Poland], Władysław Szafer Institute of Botany, Polish Academy of Sciences, Kraków.

Zarzycki K., Trzcińska-Tacik H., Różański W., Szeląg Z., Wołek T \& Korzeniak U., 2002, Ekologiczne liczby wskaźnikowe roślin naczyniowych Polski [Ecological indicator values of vascular plants of Poland], Władysław Szafer Institute of Botany, Polish Academy of Sciences, Kraków. 